\title{
EVALUASI SISTEM INFORMASI AKUNTANSI PENERIMAAN DAN PENGELUARAN KAS DANA BANTUAN OPERASIONAL SEKOLAH (BOS) (Studi Kasus Pada Sekolah Dasar Negeri Labotoy Kecamatan Kapoiala Kabupaten Konawe
}

\section{Oleh \\ Sulvariany Tamburaka ${ }^{1}$, Satira Yusuf ${ }^{2}$, Muh. Ilyas ${ }^{3}$ \\ Jurusan Akuntansi Fakultas Ekonomi dan Bisnis Universitas Halu Oleo Kendari Sulawesi Tenggara}

\begin{abstract}
ABSTRAK
Penelitian ini bertujuan untuk mengetahui dan mengevaluasi Sistem Informasi Akuntansi Penerimaan dan pengeluaran Kas Dana Program Bantuan Operasional Sekolah (BOS) di Sekolah Dasar Negeri Labotoy Kecamatan Kapoiala Kabupaten Konawe sudah sesuai dengan "Peraturan Menteri Pendidikan dan Kebudayaan Republik Indonesia nomor 1 tahun 2018 tentang Petunjuk Teknis BOS. Metode analisis yang digunakan dalam penelitian ini adalah analisis deskriptif. Hasil penelitian ini menunjukkan bahwa evaluasi sistem informasi akuntansi penerimaan dan pengeluaran kas dana BOS di Sekolah Dasar Negeri Labotoy tahun 2018 telah berjalan dengan baik dan telah sesuai dengan Peraturan Menteri Pendidikan dan Kebudayaan Nomor 1 Tahun 2018 Tentang Petunjuk Teknis Bantuan Operasional Sekolah (BOS). Namun, masih terdapat kekurangan salah satunya adalah masih ada penyusunan laporan serta transparansi laporan pertanggungjawaban dana BOS yang masih belum sesuai dengan petunjuk teknis penggunaan dana BOS. tetapi hal itu tidak mempengaruhi kegiatan penerimaan dan pengeluaran kas di Sekolah Dasar Negeri Labotoy.

Kata Kunci : Sistem Informasi Akuntansi, Penerimaan Kas, Pengeluaran Kas, Bantuan Operasional Sekolah (BOS)

ABSTRACT

This study aims to find out and evaluate the Accounting Information System for Cash Revenue and Expenditure of School Operational Assistance Program (BOS) in Labotoy State Elementary School, Kapoiala District, Konawe Regency in accordance with "Regulation of the Minister of Education and Culture of the Republic of Indonesia number 1 of 2018 concerning BOS Technical Guidelines. The analytical method used in this research is descriptive analysis. The results of this study indicate that the evaluation of the accounting information system for cash receipts and disbursements of BOS funds in Labotoy State Elementary School in 2018 has been going well and is in accordance with Minister of Education and Culture Regulation No. 1 of 2018 concerning Technical Instructions for School Operational Assistance (BOS). However, there are still shortcomings, one of which is still in preparation and transparency of the accountability report for BOS funds, which are still not in accordance with the BOS funds technical guidelines. But this does not affect the activities of cash receipts and disbursements in Labotoy state elementary school.
\end{abstract}

Keywords: Accounting Information Systems, Cash Receipts, Cash Expenditures, School Operational Assistance (BOS)

\section{PENDAHULUAN}

UU Nomor 47 tahun 2008 tentang wajib belajar menyebutkan, setiap warga negara berusia 6-15 tahun diwajibkan mengikuti pendidikan dasar sampai lulus atas biaya 
pemerintah dan atau pemerintah daerah. Pada UU Nomor 47 tahun 2008 didalamnya terdapat penjaminan wajib belajar yakni setiap warga negara Indonesia (WNI) usia wajib belajar yang berasal dari keluarga yang tidak mampu membiayai pendidikan, maka pemerintah pusat dan pemerintah daerah wajib memberikan bantuan biaya pendidikan sesuai peraturan perundang-undangan yang berlaku. Sebagai upaya untuk melaksanakan kewajiban menyelenggarakan pendidikan dasar tanpa biaya, Pemerintah menciptakan program Bantuan Operasional Sekolah (BOS). Peraturan menteri pendidikan dan kebudayaan (Permendikbud) Republik Indonesia Nomor 1 tahun 2018 menyebutkan untuk meningkatkan akses dan mutu pendidikan sebagai salah satu prioritas pembangunan nasional.

Peranan program (BOS) sangat strategis dalam percepatan pencapai target program wajib belajar Sembilan tahun sejak tahun 2005. Tercapainya Angka Partisipasi Kasar (APK) 98,2\% pada tahun 2010, sudah menunjukan bahwa ke depan program BOS tidak saja perlu di pertahankan tapi juga harus dilanjutkan. Oleh karena itu, mulai tahun 2011 pemerintah melakukan perubahan terhadap tujuan dan pendekatan atau orientasi program BOS ke depan. Peranan BOS tidak saja untuk mempertahankan APK, tetapi juga berkontribusi besar untuk memaksimalkan manfaat sistem informasi sebagai bahan olah bagi keputusan manjerial pihak sekolah. Keputusan yang tepat dan cepat akan memberikan dampak signifikan terhadap kemampuan kemajuan pendidikan.

Salah satu upaya yang dapat dilakukan agar BOS dapat tetap hidup dan mampu bersaing meningkatkan kualitas pendidikan adalah bagaimana sekolah atau perusahaan nirlaba tersebut dapat menjalankan sistem informasi dengan tepat dan cepat. Sistem informasi yang tepat dan cepat dapat membantu kebijakan manajemen dalam merencanakan program dan menjalankan kegiatan operasional sekolah sehingga dapat mencapai sasaran yang ditetapkan oleh sekolah tersebut.

Permasalahan yang sering terjadi di Sekolah Dasar pada umumnya adalah menggunakan dana BOS yang diterima tidak sesuai dengan Petunjuk Teknis BOS 2018 seperti pungutan liar praktik jual beli Lembar Kerja Siswa (LKS), penyimpangan dana BOS yang salah satu faktor penyebabnya adalah rendahnya transparansi, akuntabilitas, dan partisipasi warga atas pengelolaannya. Pengelolaan dana BOS pada tingkat sekolah selama ini cenderung tertutup dan tidak mengikuti panduan pengelolaan dana BOS sebagaimana yang telah terdapat dalam Petunjuk Teknis BOS. Kelemahan lain pelaksanaan program dana BOS adalah secara konseptual BOS diberikan kepada siswa/i tidak mampu/masyarakat miskin tetapi kenyataan lapangan belum sepenuhnya siswa/i miskin/tidak mampu mendapatkan pelayanan pendidikan secara memadai. Sehingga hal ini sangat bertentangan dengan konsep program bantuan BOS sehingga perlu diluruskan. (http://www.menkokesra.go.id/content/dana-bosrawanpenyelewengan).

Namun dengan adanya kebijakan dana BOS ini bukan berarti turut berhentinya permasalahan pendidikan di Indonesia, dalam kenyataan yang terjadi, masih dapat kita temukan berbagai kendala dalam penyaluran dan realisasi dana BOS. Berbagai masalah muncul terkait dengan adanya berbagai kasus penyelewengan dana BOS, dan mengenai ketidakefektifan pengelolaan dana BOS oleh pemerintah.

Penyimpangan dana BOS di tingkat sekolah, salah satu faktor penyebabnya adalah rendahnya transparansi, akuntabilitas, dan partisipasi warga atas pengelolaannya. Pengelolaan dana BOS pada tingkat sekolah selama ini cenderung tertutup dan tidak mengikuti panduan pengelolaan dana BOS sebagaimana yang telah dibuat oleh Kemdiknas. Sebagai contohnya, kewajiban mengumumkan APBS (Anggaran Pendapatan Belanja Sekolah) pada papan pengumuman sekolah ternyata tidak diikuti oleh sebagian besar sekolah. Selain itu, penyusunan APBS terutama pengelolaan dana bersumber dari BOS 
kurang melibatkan partisipasi orang tua murid. Akhirnya, kebocoran dana BOS di tingkat sekolah tidak dapat dihindari.

Berdasarkan hasil observasi awal yang dilakukan oleh peneliti ditemukan bahwa di Sekolah Dasar Negeri Labotoy terjadi masih kurangnya transparansi penggunaan dana BOS oleh sekolah. Hal ini terlihat penggunaan dana BOS oleh pihak sekolah yang selama ini tidak menginformasikan laporan realisasi dan rekapitulasi penggunaan dana kepada masyarakat/orang tua atau wali murid serta pihak Sekolah Dasar Negeri Labotoy tidak memasang papan informasi penggunaan dana BOS. Sedangkan didalam buku petunjuk teknis penggunaan dan pertanggungjawaban keuangan dana bantuan operasional sekolah (BOS) menyebutkan bahwa pihak sekolah harus menginformasikan secara tertulis rekapitulasi penerimaan dan penggunaan dana BOS kepada orangtua peserta didik atau mempublikasikannya melalui pemasangan pada papan informasi sekolah atau tempat lainnya yang mudah di akses oleh masyarakat.

Berdasarkan uraian mengenai latar belakang penelitian maka dapat dirumuskan rumusan masalah dalam penelitian ini adalah apakah Sistem Informasi Akuntansi Penerimaan dan Pengeluaran Kas Dana Program Bantuan Operasional Sekolah (BOS) di Sekolah Dasar Negeri Labotoy Kecamatan Kapoiala Kabupaten Konawe sudah sesuai dengan Peraturan Menteri Pendidikan dan Kebudayaan Republik Indonesia Nomor 1 Tahun 2018 Tentang Petunjuk Teknis BOS? Tujuan dari penelitian ini adalah Untuk mengetahui apakah Sistem Informasi Akuntansi Penerimaan dan Pengeluaran Kas Dana Program Bantuan Operasional Sekolah (BOS) di Seoklah Dasar Negeri Labotoy Kecamatan Kapoiala Kabupaten Konawe sudah sesuai dengan "Peraturan Menteri Pendidikan dan Kebudayaan Republik Indonesia nomor 1 tahun 2018 tentang Petunjuk Teknis BOS.

\section{Pengertian Sistem Informasi Akuntansi}

\section{TINJAUAN PUSTAKA}

Sistem informasi akuntansi adalah suatu sistem di dalam suatu organisasi yang merupakan kombinasi dari manusia, fasilitas, teknologi, media, prosedur-prosedur dan pengendalian yang ditujukan untuk mendapatkan jalur komunikasi penting, memproses tipe transaksi rutin tertentu. Manfaat dan tujuan sistem informasi akuntansi adalah sebagai berikut :

1) Mengamankan harta/kekayaan perusahaan. Harta/kekayaan di sini meliputi kas perusahaan, persediaan barang dagangan, termasuk aset tetap perusahaan. Tidak ada pemilik yang senang jika uang perusahaan dicuri orang (entah itu karyawan maupun orang asing)

2) Menghasilkan beragam informasi untuk pengambilan keputusan

3) Menghasilkan informasi untuk pihak eksternal

4) Menghasilkan informasi untuk penilaian kinerja karyawan atau divisi

5) Menyediakan data masa lalu untuk kepentingan audit (pemeriksaan)

6) Menghasilkan informasi untuk penyusunan dan evaluasi anggaran perusahaan

7) Menghasilkan informasi yang diperlukan dalam kegiatan perencanaan dan pengendalian.

Fungsi sistem informasi akuntansi:

1) Pengumpulan Data/transaksi

2) Pemrosesan Data

3) Pemanajemenan Data

4) Pengendalian dan Pengamanan Data

5) Pengadaan Informasi

6) Pertimbangan Perancangan Sistem Pemrosesan 


\section{Pengetian Sistem Akuntansi Penerimaan Kas}

Sistem akuntansi penerimaan kas yaitu suatu jaringan prosedur yang menangani suatu peristiwa suatu kejadian yang mengakibatkan terjadinya penambahan uang dalam kas yang berasal dari penjualan tunai maupun piutang yang melibatkan bagian-bagian yang saling berkaitan satu sama lain.

\section{Pengertian Sistem Akuntansi Pengeluaran Kas}

Sistem akuntansi pengeluaran kas pada umumnya didefinisikan sebagai formulir, catatan dan laporan yang dibuat untuk melaksanakan kegiatan pengeluaran baik dengan cek maupun dengan uang tunai untuk mempermudah setiap pembiayaan pengelolaan perusahaan.

\section{Pengertian Bantuan Operasional Sekolah (BOS)}

Bantuan Operasional Sekolah (BOS) menurut peraturan kemendikbud republik Indonesia nomor 1 tahun 2018 tentang petunjuk teknis BOS adalah program pemerintah yang pada dasarnya adalah untuk penyediaan pendanaan biaya operasi non personalia bagi satuan pendidikan dasar sebagai pelaksana program wajib belajar. Tujuan Bantuan Operasional Sekolah (BOS) pada SD/SDLB/SMP/SMPLB untuk:

a. Membantu penyediaan pendanaan biaya operasi non personil sekolah, akan tetapi masih ada beberapa pembiayaan personil yang masih dapat dibayarkan dari dana BOS;

b. Membebaskan pungutan biaya operasi sekolah bagi peserta didik SD/SDLB/SMP/SMPLB yang diselenggarakan oleh Pemerintah Pusat atau pemerintah daerah;

c. Meringankan beban biaya operasi sekolah bagi peserta didik SD/SDLB/SMP/SMPLB yang diselenggarakan oleh masyarakat; dan/atau

d. Membebaskan pungutan peserta didik yang orangtua/walinya tidak mampu pada SD/SDLB/SMP/SMPLB yang diselenggarakan oleh masyarakat.

Pelaksanaan Dana BOS:

A. Pengelolaan BOS Menggunakan Manajemen Berbasis Sekolah

BOS dikelola oleh SD/SDLB/SMP/SMPLB dan SMA/SMALB/SMK dengan menerapkan Manajemen Berbasis Sekolah (MBS), yang memberikan kebebasan dalam perencanaan, pengelolaan, dan pengawasan program yang disesuaikan dengan kondisi dan kebutuhan sekolah. Penggunaan BOS hanya untuk kepentingan peningkatan layanan pendidikan dan tidak ada intervensi atau pemotongan dari pihak manapun. Pengelolaan BOS mengikutsertakan dewan guru dan Komite Sekolah. Dalam hal pengelolaan BOS menggunakan MBS, maka SD/SDLB/SMP/SMPLB dan SMA/SMALB/SMK harus:

1) mengelola dana secara profesional dengan menerapkan prinsip efisien, efektif, akuntabel, dan transparan;

2) melakukan evaluasi setiap tahun; 3)menyusun Rencana Kerja Jangka Menengah (RKJM), Rencana Kerja Tahunan (RKT), dan Rencana Kegiatan dan Anggaran Sekolah (RKAS), dengan ketentuan: a)RKAS memuat BOS; b)RKJM disusun setiap 4 (empat) tahun; c)RKJM, RKT, dan RKAS disusun berdasarkan hasil evaluasi diri sekolah; d)RKJM, RKT, dan RKAS harus disetujui dalam rapat dewan guru setelah memperhatikan pertimbangan Komite Sekolah dan disahkan oleh dinas pendidikan provinsi/kabupaten/ kota sesuai dengan kewenangannya.

B. Tim BOS Sekolah

1) Struktur Keanggotaan

Kepala sekolah membentuk Tim BOS Sekolah dengan susunan keanggotaan yang terdiri atas: 
a) Penanggung Jawab : Kepala Sekolah

b) Anggota : (1)Bendahara; (2) 1 (satu) orang dari unsur orang tua peserta didik di luar Komite Sekolah yang dipilih oleh kepala sekolah dan Komite Sekolah dengan mempertimbangkan kredibilitasnya, serta menghindari terjadinya konflik kepentingan; (3) Penanggung jawab pendataan.

2) Penetapan Alokasi BOS Tiap Sekolah

A. Tim BOS Provinsi mengunduh data jumlah peserta didik di tiap sekolah dari Dapodik yang selanjutnya digunakan dalam perhitungan alokasi BOS tiap sekolah. Data yang diunduh merupakan data dari Dapodik yang telah diambil (cut off) oleh Tim Dapodik Kementerian Pendidikan dan Kebudayaan.

B. Alokasi BOS untuk sekolah ditetapkan dengan ketentuan berikut:

a) Data yang dijadikan sebagai acuan yaitu:

(1) data hasil cut off sebelum triwulan/semester berjalan, yang digunakan sebagai dasar penyaluran awal. Penggunaan data ini dengan mempertimbangkan agar proses pencairan BOS sudah dapat dilakukan sebelum masuk triwulan/semester sehingga sekolah dapat menerima BOS di awal triwulan/semester;

(2) data hasil cut off pada triwulan/semester berjalan yang digunakan untuk informasi pelengkap dalam perhitungan kelebihan atau kekurangan penyaluran BOS di triwulan/semester berkenaan yang sudah dilakukan menggunakan data sebelum triwulan/semester berkenaan.

b) Cut off data yang dilaksanakan dalam rangka pengambilan data untuk penetapan alokasi di sekolah yaitu:

(1) cut off tanggal 15 Desember. Data yang diambil merupakan data jumlah peserta didik semester I Tahun Ajaran berkenaan;

(2) cut off tanggal 30 Januari. Data yang diambil merupakan data jumlah peserta didik semester II Tahun Ajaran berkenaan. Apabila sekolah belum melakukan update data jumlah peserta didik semester II Tahun Ajaran berkenaan, maka data jumlah peserta didik yang diambil merupakan data jumlah peserta didik semester I Tahun Ajaran berkenaan;

(3)cut off tanggal 30 April. Data yang diambil merupakan data jumlah peserta didik semester II Tahun Ajaran berkenaan;

(4)cut off tanggal 21 September, diharapkan update data peserta didik tahun ajaran baru oleh sekolah telah selesai dan Tim BOS Provinsi masih memiliki waktu yang cukup untuk mempersiapkan proses pencairan dana BOS. Data yang diambil merupakan data jumlah peserta didik semester I Tahun Ajaran berkenaan. Apabila sekolah belum melakukan update data jumlah peserta didik semester I Tahun Ajaran berkenaan, maka data jumlah peserta didik yang diambil merupakan data jumlah peserta didik semester II Tahun Ajaran sebelumnya;

(5)cut off tanggal 30 Oktober. Data yang diambil merupakan data jumlah peserta didik semester I Tahun Ajaran berkenaan.

c) Untuk penyaluran BOS triwulanan, perhitungan alokasi tiap sekolah dilakukan dengan ketentuan sebagai berikut:

(1) Triwulan I 
(a) Perhitungan alokasi sementara tiap sekolah untuk penyaluran BOS triwulan I menggunakan data jumlah peserta didik hasil cut off Dapodik tanggal 15 Desember dan disesuaikan dengan ketentuan/ kebijakan perhitungan alokasi sekolah yang berlaku.

(b) Perhitungan alokasi final triwulan I untuk tiap sekolah dilakukan dengan membandingkan data jumlah peserta didik masing-masing sekolah pada hasil cut off tanggal 15 Desember dan hasil cut off tanggal 30 Januari.

(2) Triwulan II

(a) Perhitungan alokasi sementara tiap sekolah untuk penyaluran BOS triwulan II menggunakan data jumlah peserta didik hasil cut off Dapodik tanggal 30 Januari, dan disesuaikan dengan ketentuan/ kebijakan perhitungan alokasi sekolah yang berlaku.

(b) Perhitungan alokasi final triwulan II untuk tiap sekolah dilakukan dengan membandingkan data jumlah peserta didik masing-masing sekolah pada hasil cut off tanggal 30 Januari dan hasil cut off tanggal 30 April.

(3) Triwulan III

(a) Perhitungan alokasi sementara tiap sekolah untuk penyaluran BOS triwulan III menggunakan data jumlah peserta didik hasil cut off Dapodik tanggal 30 April, dan disesuaikan dengan ketentuan/kebijakan perhitungan alokasi sekolah yang berlaku.

(b) Perhitungan alokasi final triwulan III untuk tiap sekolah dilakukan dengan membandingkan data jumlah peserta didik masing-masing sekolah pada hasil cut off tanggal 30 April dan hasil cut off tanggal 30 Oktober.

(4) Triwulan IV

(a) Perhitungan alokasi sementara tiap sekolah untuk penyaluran BOS triwulan IV menggunakan data jumlah peserta didik hasil cut off Dapodik tanggal 21 September, dan disesuaikan dengan ketentuan/ kebijakan perhitungan alokasi sekolah yang berlaku.

(b) Perhitungan alokasi final triwulan IV untuk tiap sekolah dilakukan dengan membandingkan data jumlah peserta didik masing-masing sekolah pada hasil cut off tanggal 21 September dan hasil cut off tanggal 30 Oktober.

3) Penyaluran dana BOS

Proses pemyaluran dana BOS dari tingkat pusat sampai dengan tingkat sekolah dilakukan dua tahap, yaitu Tahap 1: penyaluran dana dari Rekening Kas Umum Negara (RKUN) ke Rekening Kas Umum Daerah (RKUD) Provinsi. Mekanisme penyaluran dana dan pelaopran diatur dalam Peraturan Menteri Keuangaan (PMK). Tahap 2: penyaluran dana dari KUD provinsi ke rekening sekolah. Mekanisme penyaluran dana dan pelaporannya akan diatur dalam peraturan Meneteri Dalam Negeri. Proporsi penyaluran dana tiap triwulan /semester dari RKUN ke RKUD diatur dengan ketentuan persentase sebagai berikut : 
Tabel 2.2

Penyaluran Tiap Triwulan

\begin{tabular}{|c|c|c|c|}
\hline No. & Triwulan & Bulan & Persen (\%) \\
\hline 1. & Triwulan I & Januari - Maret & $20 \%$ \\
\hline 2. & Triwulan II & April - Juni & $40 \%$ \\
\hline 3. & Triwulan III & Juli - September & $20 \%$ \\
\hline 4. & Triwulan IV & $\begin{array}{c}\text { Oktober - } \\
\text { Desember }\end{array}$ & $20 \%$ \\
\hline
\end{tabular}

Sumber: Petunjuk Teknis Penggunaan Dana BOS Tahun Anggaran 2018

4) Pengambilan dana BOS

Pengambilan dana BOS dilakukan oleh bendahara sekolah atas persetujuan kepala sekolah dan dapat dilkukan sewaktu-waktu sesuai kebutuhan dengan menyisakan saldo minimum sesuai peraturan yang berlaku. Dana BOS harus diterima secara utuh oleh sekolah dan tidak diperkenankan adanya pemotongan atau pemungutan biaya apapun dengan alasan apapun dan oleh pihak manapun. Dana bos dalam suatu periode tidak harus habis dipergunakan pada periode tersebut. Besar penggunaan dana tiap bulan disesuaiakan dengan kebutuhan sekolah sebagaimana tertuang dalam rencana kegiatan dan anggaran sekolah (RKAS).

5) Penggunaan dana BOS

Penggunaan dana BOS di sekolah harus didasarkan paada kesepakatan dan keputusan bersama antara Tim Manajemen BOS sekolah, Dewan Guru dan Komite Sekolah. Hasil kesepakatan harus dituangkan secara tertulis dalam bentuk berita acara rapat dan ditanda tangani oleh peserta rapat. Dana BOS yang diterima oleh sekolah, dapat digunakan untuk membiayai komponen-komponen kegiatan berikut: 1) pengembangan perpustakaan, 2) kegiatan dalam rangka penerimaan siswa baru, 3) kegiatan pembelajaran dan ekstrakurikuler siswa, 4) kegiatan ulangan dan ujian, 5) pembelian bahan-bahan habis pakai, 6) langganan daaya dan jasa, 7) perawatan sekolah, 8) pembayaran honorarium bulanan guru honorer dan tenaga kependidikan honorer, 9) pengembangan profesi guru, 10) membantu siswa miskin, 11) pembiayaan pengelolaan BOS, 12) pemebelian perangkat komputer, 13) biaya lainnya jika seluruh komponen $1 \mathrm{~s} / \mathrm{d} 12$ telah terpenuhi pendanaannya dari BOS.

Pembukuan, Laporan dan Transparansi Dana BOS secara umum hal-hal yang dilaporkan oleh pelaksana program adalah yang berkaitan dengan statistik penerima bantuan, penyaluran, penyerapan, pemanafaatan dana, pertanggungjawaban keuangan serta hasil monitoring evaluasi dan pengaduan masalah.

1) Pembukuan, adapun pembukuan dan dokumen pendukung yang harus disusun oleh sekolah dengan ketentuan sebagai berikut:

a. Rencana Kegiatan dan Anggaran Sekolah

RKAS ditandatangani oleh Kepala Sekolah, Komite Sekolah, dan Ketua Yayasan (khusus untuk sekolah yang diselenggarakan masyarakat). RKAS harus dilengkapi dengan rencana penggunaan dana secara rinci, yang dibuat tahunan dan triwulan untuk setiap sumber dana yang diterima sekolah.

b. Buku Kas Umum (BKU)

Disusun untuk masing-masing rekening Bank yang dimiliki oleh sekolah. Pembukuan BKU meliputi semua transaksi eksternal, yaitu 
yang berhubungan dengan pihak ketiga dengan ketentuan dimana kolom penerimaan memuat penerimaan dari penyalur dana, penerima dari pemungutan pajak, dan penerimaan jasa giro dari bank, dan kolom pengeluaran memuat pengeluaran untuk pembelian barang dan jasa, biaya administrasi bank, pajak atas hasil dari jasa giro, dan setoran pajak.

c. Buku Pembantu Kas

Buku ini harus mencatat tiap transaksi tunai dan ditandatangani oleh Bendahara dan Kepala Sekolah.

d. Buku Pembantu Bank

Buku ini mencatat tiap transaksi melalui bank (baik cek, giro, maupun tunai) dan ditandatangani oleh Bendahara dan Kepala Sekolah.

e. Buku Pembantu Pajak

Buku ini berfungsi mencatat semua transaksi yang harus dipungut pajak serta memonitor pungutan dan penyetoran pajak yang dipungut selaku wajib pungut pajak.

f. Opname Kas dan Berita Acara Pemeriksaan Kas

Setiap akhir bulan BKU ditutup dan ditandatangani oleh Kepala Sekolah dan Bendahara. Sebelum penutupan BKU, Kepala Sekolah melakukan opname kas dengan menghitung jumlah kas baik yang ada di sekolah (kas tunai) maupun kas yang ada di bank (rekening sekolah). Hasil dari opname kas kemudian dibandingkan dengan saldo akhir BKU pada bulan bersangkutan. Apabila terjadi perbedaan, maka harus dijelaskan penyebab perbedaannya. Setelah pelaksanaan opname kas, maka Kepala Sekolah dan Bendahara menandatangani Berita Acara Pemeriksaan Kas.

g. Bukti pengeluaran

1. Setiap transaksi pengeluaran harus didukung dengan bukti kuitansi yang sah.

2. Bukti pengeluaran uang dalam jumlah tertentu harus dibubuhi materai yang cukup sesuai dengan ketentuan peraturan perundangundangan mengenai bea materai.

3. Uraian pembayaran dalam kuitansi harus jelas dan terinci sesuai dengan peruntukannya.

4. Uraian tentang jenis barang/jasa yang dibayar dapat dipisah dalam bentuk faktur sebagai lampiran kuitansi.

5. Setiap bukti pembayaran harus disetujui Kepala Sekolah dan dibayar lunas oleh Bendahara.

6. Segala jenis bukti pengeluaran harus disimpan oleh Bendahara sebagai bahan bukti dan bahan laporan.

2) Pelaporan

Pelaporan tingkat sekolah terdiri atas: a) rencana kegiatan dan anggaran sekolah (formulir BOS-K1 dan BOS K-2, b) pembukuan, c) realisasi penggunaan dana tiap sumber dana (Formulir BOS-K7), d) rekapitulasi realisasi penggunaan dana BOS (Formulir BOS-K7a), e) bukti pengeluaran, f) pelaporan

Pelaporan tingkat kabupaten / kota (Formulir BOS-K8): a) rekapitulasi penggunaan dana BOS yang diperoleh dari tim manajemen BOS Sekolah dengan menggunakan formulir BOS-K8, b) penggunaan pengaduan masyarakat yang antara lain berisi informasi tentang jenis kasus, skala kasus, kemajuan penanganan dan status penyelesaian. Pelaporan tingkat provinsi: a) laporan triwulanan (Formulir BOS-K9a), 
b) laporan akhir tahun (Formulir BOS-K10), c) hasil monitoring dan evaluasi. Pelaporan tingkat pusat meliputi: a) laporan triwulanan (Formulir BOS-K11a), laporan akhir tahun (Formulir BOS-K12).

\section{3) Transparansi}

Sebagai salah satu bentuk tanggung jawab dalam pengelolaan program dan penggunaan BOS, sekolah harus menyusun dan mempublikasikan dokumen pendukung transparansi informasi secara lengkap. Dokumen pendukung yang wajib dipublikasikan oleh sekolah meliputi Realisasi Penggunaan Dana Tiap Sumber Dana, dokumen yang digunakan adalah laporan realisasi penggunaan dana tiap sumber dana dan Rekapitulasi Realisasi Penggunaan Dana, dokumen yang digunakan adalah laporan rekapitulasi penggunaan dana berdasarkan komponen pembiayaan BOS. Dimana kedua dokumen Laporan ini harus dipublikasikan setiap triwulan mengikuti periode pembuatan laporan tersebut. Publikasi laporan dilakukan melalui pemasangan pada papan informasi sekolah atau tempat lainnya yang mudah diakses oleh masyarakat.

\section{Pertanggungjawaban Dana BOS}

Pertanggungjawaban (Mardiasmo) adalah sebuah kewajiban melaporkan dan bertanggungjawab atas keberhasilan ataupun kegagalan pelaksanaan misi organisasi dalam mencapai hasil yang telah ditetapkan sebelumnya, melalui media pertanggungjaaban yang dikerjakan secara berkala.

Pertanggungjawaban sekolah kepada pemerintah dengan memberikan laporan Pengelolaan Dana BOS pada setiap akhir periode Dana BOS. Adapun pihak-pihak yang diberikan laporan Dana BOS adalah Dinas Pendidikan Kabupaten, Dinas Pendidikan Provinsi dan Dinas Pusat. Laporan untuk Provinsi berupa email, laporan ringkas dan disertakan bukti laporan lengkap saat melakukan pelaporan langsung di Dinas Pendidikan Provinsi. Laporan untuk Kabupaten berupa laporan ringkas dan laporan untuk Dinas Pusat di Jakarta melalui email. Selain dinas-dinas tersebut, sekolah juga melaporkan Pengelolaan Dana BOS pada Komite Sekolah. Kegiatan Pelaporan yang dibuat sebagai bentuk pertanggungjawaban sekolah atas keterlaksanaan Dana BOS kepada pemerintah pusat dibuat oleh Sekolah dan secara khusus oleh Kepala Sekolah dan Bendahara BOS

\section{Kerangka Pikir Penelitian}

\section{Kerangka Pikir}

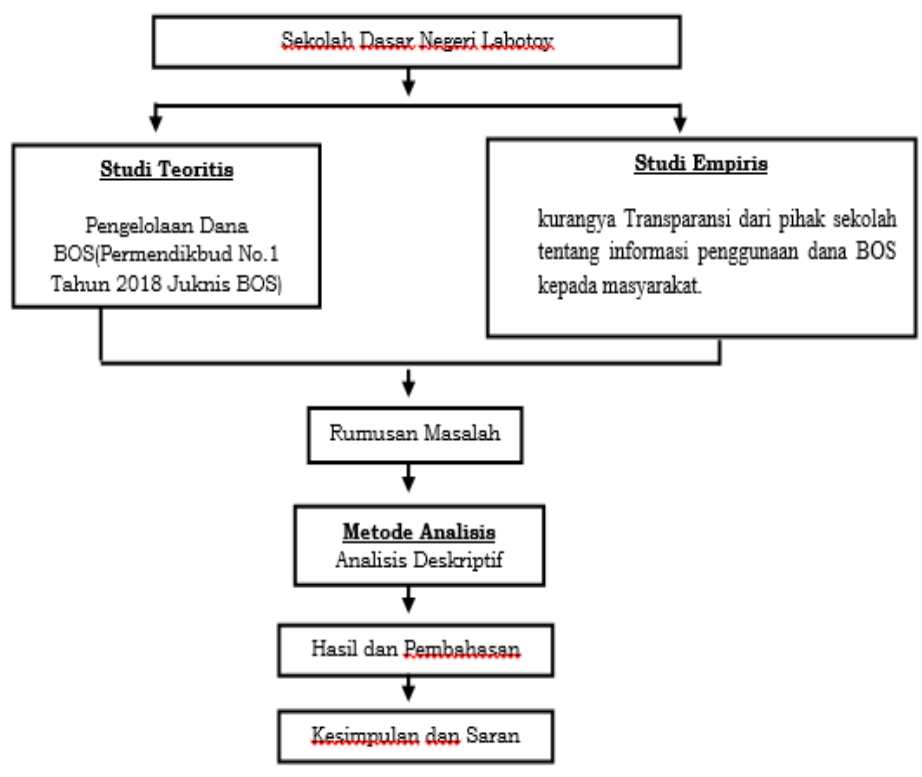




\section{METODE PENELITIAN}

Objek dalam penelitian ini adalah Evaluasi Sistem Informasi Akuntansi Penerimaan dan Pengeluaran Kas Dana Program Bantuan Operasional Sekolah (BOS) pada Sekolah Dasar Negeri Labotoy. Jenis data dalam penelitian ini adalah Data kuantitatif berupa data keuangan Sekolah Dasar Negeri Labotoy yakni laporan pertanggungjawaban Dana BOS 2018. Data kualitatif dalam penelitian ini berupa informasi mengenai gambaran umum tempat penelitian. Sumber data yang digunakan dalam penelitian ini adalah data Primer yaitu berupa wawancara kepada kepala sekolah, bendahara sekolah dan komite sekolah. Data sekunder dalam penelitian ini berupa dokumen/arsip sekolah berupa profil sekola, dapodik dan laporan pertanggungjawaban dna BOS 2018 pada satuan Pendidikan Sekolah Dasar Negeri Labotoy Kecamatan Kapoiala Kabupaten Konawe.

Metode pengumpulan data yang digunakan adalah dokumen, wawancara, dokumentasi dan observasi. Metode analisis data yang digunakan dalam penelitian ini adalah analisis deskriptif. Metode Analisis deskriptif menganalisis data yang dihasilkan melalui wawancara terhadap subyek penelitian, sehingga peneliti dapat memecahkan pokok persoalan yang timbul dalam penelitian ini. Selanjutnya peneliti dapat menyimpulkan beberapa pokok persoalan berikut pemecahan masalahnya juga peneliti dapat memberikan beberapa saran yang merupakan bagian dari solusi dalam memecahkan persoalan yang timbul dalam penelitian ini.

\section{HASIL DAN PEMBAHASAN}

\section{Hasil Penelitian}

\section{A. Penerimaan Kas Dana BOS}

Dari hasil penelitian yang diperoleh bahwa mekanisme penerimaan kas dana BOS di Sekolah Dasar Negeri Labotoy adalah dimulai dari pihak sekolah dalam hal ini Kepala Sekolah dan Bendahara mengambil dana BOS yang diterima dari KASDA masing-masing wilayah yang telah disalurkan ke dalam rekening sekolah melalui bank. Selanjutnya bendahara membuat laporan penerimaan dana dan mengalokasikan dana BOS sesuai dengan Rencana Kegiatan Anggaran Sekolah (RKAS) yang telah dibuat dan disepakati, dalam hal ini di Sekolah Dasar Negeri Labotoy dalam bentuk Rencana Anggaran Pendapatan dan Belanja Sekolah (RAPBS).

Sebagaimana hasil wawancara dengan Kepala Sekolah SD Negeri Labotoy dalam hal ini bapak Sarman, A.Ma mengatakan bahwa "untuk proses penerimaannya itu kita menerima dana BOS ini setiap triwulan yang mana dari pihak sekolah saya selaku kepala sekolah bersama bendahara melakukan pencairan/penerimaan dana BOS yang telah disalurkan ke rekening sekolah melalui bank".

\section{B. Pengeluaran Kas Dana BOS}

Dari hasil penelitian yang diperoleh bahwa mekanisme/prose pengeluaran kas dana BOS di Sekolah Dasar Negeri Labotoy dimulai setelah bendahara menerima dana BOS yang telah diterima melalui rekening sekolah, kemudian bendahara mengalokasikan dana bos sesuai dengan apa yang telah tertuang dalam RKAS yang telah dibuat dan disepakati dalam hal ini di Sekolah Dasar Negeri Labotoy dalam bentuk RAPBS, lalu bendahara menginformasikan atau menkonfirmasi setiap proses pembelian atau pembiayaan yang dilakukan serta menyiapkan bukti/dokumen dasar dan dokumen pendukung transaksi setiap pengeluaran kas dan laporan realisai penggunaan dana.

Sebagaimana hasil wawancara dengan Bendahara Sekolah SD Negeri Labotoy dalam hal ini Ibu Muliana, S.Pd, mengatakan bahwa "Kalau untuk proses pengeluaran kasnya itu dikeluaran sesuai dengan RAPBS yang sudah disusun dan setiap melakukan 
pembelian barang atau pengeluaran kas harus diinformasikan/dikonfirmasi kepada kepala sekolah, diotorisasi oleh kepala sekolah dan pastinya harus lengkap bukti pengeluarannya seperti nota, kwitansi sama BKU nya termaksud laporan realisasinya dari kegitan-kegiatan yang dilaksanakan".

\section{Pembahasan}

\section{A. Prosedur Penerimaan Kas Dana BOS}

Adapun Prosedur penerimaan kas dana BOS sesuai dengan Peraturan Menteri Pendidikan dan Kebudayaan Republik Indonesia Nomor 1 Tahun 2018 Tentang Petunjuk Teknis BOS adalah dimulai dari dengan prosedur pengalokasian, dalam hal penerimaan dana BOS dimulai dengan beberapa orang yang mempunyai wewenang diantaranya yaitu oleh :

1. Operator Sekolah melakukan pengisian, pengiriman, dan peng-updatetan data pokok pendidikan secara lengkap kedalam suatu sistem yang bernama dapodikmen.

2. Bagian Tata Usaha membuat segala administrasi data peserta didik serta menggandakan formulir dapodik sesuai dengan kebutuhan

3. Bendahara BOS melakukan verivikasi kesesuaian jumlah data peserta didik maupun kas dengan data yang ada selanjutnya membuat RAB.

Adapun Waktu Penyaluran Dana BOS dibagi dalam tiap triwulan sebagaimana dapat dilihat pada table 2.1. Proses penyaluran dana BOS dari tingkat pusat sampai dengan tingkat sekolah dilakukan dua tahap, yaitu:

- Tahap 1: penyaluran dana dari Rekening Kas Umum Negara (RKUN) ke Rekening Kas Umum Daerah (RKUD) Provinsi. BOS disalurkan dari RKUN ke RKUD setiap triwulan pada waktu yang ditentukan sesuai peraturan perundang-undangan.

- Tahap 2: penyaluran dana dari RKUD provinsi ke rekening sekolah. Mekanisme penyaluran adalah Bendahara Umum Daerah (BUD) harus menyalurkan BOS secara langsung ke rekening sekolah sesuai dengan ketentuan peraturan perundangundangan.

Untuk penerimaan dana BOS sendiri terbagi menjadi 4 tahap dalam hal ini tiap triwulan, adapun syarat penerimaan untuk triwulan II sampai triwulan ke IV yaitu menyetor laporan penerimaan serta realisasi penggunaan dana dari kegiatan setiap triwulannya yang telah dibayarkan sesuai dalam RKAS sekolah yang telah disepakati.

Mekanisme Pengambilan dana BOS dimulai dari pihak sekolah yaitu Kepala Sekolah dan Bendahara mengambil dana BOS melalui bank yang diterima dari dinas pendidikan pusat yang telah disalurkan melalui RKUN ke RKUD masing-masing wilayah yang selanjutnya disalurkan dalam rekening sekolah masing-masing. Selanjutnya bendahara membuat laporan penerimaan dana dan mengalokasikan dana BOS yang telah diterima sesuai dengan RKAS. Dana BOS harus diterima secara utuh oleh sekolah dan tidak diperkenankan adanya pemotongan biaya apapun dengan alasan apapun dan oleh pihak manapun. Fungsi terkait dalam prosedur penerimaan ini yaitu Kepala Sekolah dan Bendahara. Adapun contoh jurnal Penerimaan dana BOS ini adalah:

Contoh:

Kas Rp. XXX

Dana BOS Rp. XXX

\section{B. Prosedur Pengeluaran Kas Dana BOS}

Adapun Prosedur pengalokasian Pengeluaran kas dana BOS sesuai dengan Peraturan Menteri Pendidikan dan Kebudayaan Republik Indonesia Nomor 1 Tahun 2018 Tentang Petunjuk Teknis BOS adalah pengeluaran dana BOS di sekolah harus didasarkan 
pada kesepakatan dan keputusan bersama antara Tim BOS Sekolah, Dewan Guru, dan Komite Sekolah. Hasil kesepakatan di atas harus dituangkan secara tertulis dalam bentuk berita acara rapat dan ditandatangani oleh peserta rapat. Kesepakatan penggunaan BOS harus didasarkan skala prioritas kebutuhan sekolah, khususnya untuk membantu mempercepat pemenuhan Standar Pelayanan Minimal (SPM) dan/atau Standar Nasional Pendidikan (SNP). Penggunaan BOS diprioritaskan untuk kegiatan operasional sekolah. Prosedur pengeluaran Dana BOS dimulai dari membuat surat permintaan pembelian atau pengeluaran yang dilakukan oleh bagian yang sudah ditetapkan, kemudian menyerahkan ke Staf Tata Usaha atau Bendahara Sekolah selanjutnya dikonfirmasikan ke Kepala Sekolah.

Fungsi yang terkait dalam hal pengeluaran Kas yaitu kepala sekolah, bendahara sekolah dan guru. Adapun contoh jurnal untuk Pengeluaran kas dana BOS di Sekolah Dasar Negeri Labotoy ini antara lain adalah:

1. Kegiatan Pembayaran Honor Guru GTT

Beban Honor

Kas

Rp. XX

Rp. XX

2. Kegiatan Pemeliharaan dan Perawatan Sarpras Sekolah

Biaya pemeliharaan \& perawatan sarpras sekolah Kas

Rp. XX

RP. XX

3. Kegiatan Pembayaran Langganan Daya dan Jasa

Beban langganan daya $\&$ jasa

Kas

Rp. XX

4. Kegiatan Evaluasi Pembelajaran

Beban Evaluasi Pembelajaran

Kas

5. Kegiatan Pengelolaaan Sekolah

Biaya Pengelolaan Sekolah

Kas

\section{Evaluasi Pengelolaan Dana Bantuan Operasional Sekolah}

Rp. XX

Rp. XX

Evaluasi SIA Penerimaan dan Pengeluaran Kas SD Negeri labotoy dilihat dari hasil wawancara peneliti mengenai laporan pertanggung jawaban penggunaan dana BOS bahwa SD Negeri Labotoy sudah sesuai prosedur petunjuk teknis BOS dalam Permendikbud RI Nomor 1 Tahun 2018 yang telah dijelaskan sebelumnya. Dapat dilihat dokumen atau formulir yang digunakan dalam sistem pendapatan dan penerimaan kas pada Sekolah Dasar Negeri labotoy sudah cukup memadai. Hal tersebut dapat dilihat dari dokumen yang digunakan dalam transaksi penerimaan kas dana BOS. Formulir Pendaftaran. Dokumen ini berisi data siswa dan sekolah seperti nama siswa, jumlah siswa, nama guru dan karyawan serta alamat guru, karyawan dan siswa, tetapi didalam laporan pertanggungjawabannya pihak sekolah tidak membuat laporan penerimaan dana BOS yang dibuat oleh bendahara dan hanya membuat RAPBS saja dalam laporan pertanggungjawaban penggunaan dana BOS, dan RAPBS yang di buat hanya tiga triwulan saja dalam hal ini hanya RAPBS untuk periode bulan januari-september, yang dimana seharusnya didalam pertanggugjawaban keuangan dalam pengelolaan dana BOS, sekolah harus menyususn pembukuan secara lengkap sesuai dengan petunjuk teknis yang dimana pembukuan dan dokumen yang harus disusun oleh sekolah ialah adanya RKAS. RKAS atau Rencana Kegiatan dan Anggaran Sekolah berisi tentang kegiatan rencana anggaran sekolah dalam 1 tahun yang meliputi pendapatan rutin spp sekolah, bantuan dari dana BOS baik itu BOS pusat atau berasal dari provinsi atau BOS daerah atau disebut BKSM yang wajib ditandatangani oleh Kepala Sekolah, Ketua Yayasan (khusus untuk sekolah yang diselenggarakan oleh masyarakat), 
dan Komite Sekolah.

Sistem penerimaan dan pengeluaran kas dana Bantuan Operasional Sekolah (BOS) sudah berjalan dengan baik. Hal ini dapat dilihat dari hasil penelitian dan wawancara yang telah diuraikan sebelumnya. Hanya saja perlu diperhatikan dalam membuat atau mengolah dokumen agar senantiasa sesuai dengan peraturan yang telah ditetapkan, agar dokumen yang digunakan sesuai dengan peraturan yang berlaku.

Dokumen atau formulir yang digunakan dalam sistem pembelian dan pengeluaran kas pada SD Negeri Laboty sudah cukup memadai. Hal tersebut dapat dilihat dari dokumen yang digunakan dalam transaksi pembelian dan pengeluaran kas pada SD Negeri Laboty adalah:

1. Surat permintaan pembelian, dokumen ini merupakan formulir yang diisi oleh fungsi tata usaha sub unit perlengakapan kantor untuk meminta bendahara sekolah melakukan pembelian barang dengan jenis, jumlah, dan spesifikasi yang diminta.

2. SK (Surat Keputusan), dokumen ini merupakan anggaran yang dibuat oleh masingmasing unit setiap bulannya.

3. Faktur dari pemasok, dokumen ini merupakan tagihan dari pemasok, yang berisi jenis, kuantitas, dan harga barang yang menjadi kewajiban sekolah kepada pemasok.

4. Kuintansi Pembelian, dokumen ini untuk transaksi biaya honorarium, biaya fotocopy dan konsumsi guru dan karyawan. Dokumen ini terdiri dari 2 rangkap, satu lembar untuk unit tata usaha sub bagian akuntansi dan satu lembar kuintansi diberikan untuk bendahara sekolah.

Dari hasil evaluasi sistem informasi akuntansi penerimaan dan pengeluaran kas dana BOS di SD Negeri Labotoy dalam pelaksanaanya telah berjalan dengan baik, dapat dilihat dari hasil penelitian, wawancara dan observasi lapangan yang dijelaskan sebelumnnya, tetapi masih terdapat beberapa kekurangan salah satunya dalam hal penerimaan bendahara sekolah tidak membuat laporan penerimaan dana BOS yang diterima melalui Bank, penyusunan laporan pertanggungjawaban yang masih belum sesuai dengan Peraturan Menteri Pendidikan dan Kebudayaan Republik Indonesia Nomor 1 Tahun 2018 Tentang Petunjuk Teknis BOS

\section{Kesimpulan}

\section{KESIMPULAN DAN SARAN}

Berdasarkan hasil penelitian dan pembahasan yang telah diuraikan dapat disimpulkan bahwa Evaluasi Sistem Informasi Akuntansi Penerimaan dan Pengeluaran Kas Dana BOS di Sekolah Dasar Negeri Labotoy tahun 2018 telah berjalan dengan baik. Hal itu dapat dilihat dari penjelasan tentang penerimaan dan pengeluaran kas dana BOS telah sesuai dengan petunjuk teknis BOS yang terdapat dalam Permendikbud Nomor 1 tahun 2018. Namun, masih terdapat kekurangan salah satunya adalah masih ada penyusunan laporan serta transparansi laporan pertanggungjawaban dana BOS yang masih belum sesuai dengan petunjuk teknis penggunaan dana BOS. tetapi hal itu tidak mempengaruhi kegiatan penerimaan dan pengeluaran kas di Sekolah Dasar Negeri Labotoy.

\section{Implikasi}

Dari hasil penelitian tersebut dapat di kemukakan implikasi sebagai berikut:

1. Bagi Sekolah Dasar Negeri Labotoy

Dengan adanya penelitian ini, dapat memberikan masukan bagi Sekolah Dasar Negeri Labotoy tentang Sistem Informasi Akuntansi Penerimaan dan Pengeluaran Kas Dana Program Bantuan Operasional Sekolah (BOS). 
2. Bagi peneliti

Untuk menambah dan memperdalam wawasan serta pengetahuan peneliti tentang sistem informasi akuntansi atas penerimaan dan pengeluaran dana program Bantuan Operasional Sekolah (BOS).

3. Bagi Peneliti Selanjutnya

Penelitian ini diharapkan dapat menambah pengetahuan dan pemahaman serta nantinya dapat dijadikan sebagai salah satu bahan referensi pengetahuan, bahan diskusi, dan bahan kajian lanjutan bagi pembaca tentang masalah yang berkaitan dengan sistem informasi akuntansi atas penerimaan dan pengeluaran dana program Bantuan Operasional Sekolah (BOS).

\section{Keterbatasan}

Penelitian yang dilaukan hanya menjelaskan Sistem Informasi Akuntansi Penerimaan dan Pengeluaran Kas Dana Program Bantuan Operasional Sekolah (BOS) pada Sekolah Dasar Negeri Labotoy dan peneliti hanya meneliti data penerimaan dan pengeluaran hanya III triwulan pelaporan dikarenakan dari pihak sekolah hanya memberikan data tersebut.

\section{Saran}

Dalam hal penerimaan dan pengeluaran dana BOS tidak lepas dari peran semua pihak sekolah baik tim BOS sekolah, komite sekolah dan dewan guru. Oleh karenanya pihak sekolah perlu menjalin komunikasi yang baik dan terbuka dalam pengelolaannya agar kedepannya Penggunaan dan penyusunan laporan pertanggungjawaban dana BOS sesuai dengan peraturan yang ditetapkan. Untuk peneliti selanjutnya yang hendak melakukan penelitian tentang dana BOS di Sekolah Dasar Negeri Labotoy penulis menyarankan agar meneliti Evaluasi tentang dana BOS dalam satu tahun periode pelaporan atau empat triwulan dan tentang sejauh mana efektivitas dana BOS dalam memajukan pendidikan di Sekolah Dasar Negeri Labotoy.

\section{DAFTAR PUSTAKA}

Anastasia Diana, Lilis Setiawati. 2011. Sistem Informasi Akuntansi, Perancangan, Prosedur dan Penerapan. Edisi 1. Yogyakarta: Andi Yogyakarta.

Baridwan, Zaki. 2010. Sistem Akuntansi Penyusunan Prosedur Dan Metode. Edisi 5. Yogyakarta : BPPE.

Halim, Abdul. 2010. Sistem Akuntansi Sektor Publik. Yogyakarta : Sekolah Tinggi Ilmu Manajemen YKPN.

Herliana, Cici Larasati. 2018. Evaluasi Sistem Informasi Akuntansi Penerimaan Dan pengeluaran Dana Bantuan Operasional Sekolah (BOS) Di SMA PGRI Puri Kabupaten Mojokerto. Mojokerto. Skripsi.

Krismiaji. 2010. Sistem Informasi Akuntansi edisi ketiga. Yogyakarta : Unit Penerbit dan Percetakan Sekolah Tinggi Ilmu Manajemen YKPN.

Krismiaji. 2015. Sistem Informasi Akuntansi edisi keempat. Yogyakarta : Unit Penerbit dan Percetakan Sekolah Tinggi Ilmu Manajemen YKPN.

Mahayusa, Putu Wahyu. 2017. Evaluasi Sistem Informasi Akuntansi Atas Prosedur Penerimaan Dan Pengeluaran Kas Dana Program Bantuan Operasional Sekolah Sebagai Penyedia Informasi Pengendalian Internal PadaSekolah Menengah Atas Negeri 1 Busungbiu Kabupaten Buleleng. Buleleng. Skripsi

Marshall B. Romney Dan Paul John Steinbart. 2014. Sistem Informasi Akuntansi: Accounting Information Systems (Edisi 13). Prentice Hall. 
Peraturan Menteri Pendidikan dan Kebudayaan Republik Indonesia No. 1 Tahun 2018 Tentang Petunjuk Teknis BOS.

Sari Destina. 2017. Evaluasi Sistem Informasi Akuntansi Atas Prosedur Penerimaan Dan Pengeluaran Dana Bantuan Operasional Sekolah(BOS) Pada Sekolah Menengah Pertama Negeri 2 Andong Boyolali. Boyolali. Skripsi.

Undang-Undang No. 47 Tahun 2008 Tentang Pelaksanaan Wajib Belajar 9 Tahun. Website:http://www.menkokesra.go.id/content/dana-bosrawanpenyelewengan dikutip pada Selasa 21 November 2019 pukul 23.36 